\title{
Relación entre las variables ambientales y el crecimiento de Pteria colymbus (Mollusca Bivalvia: Pteriidae), en tres profundidades de cultivo
}

\author{
Relationship between environmental variables and growth of \\ Pteria colymbus (Mollusca Bivalvia: Pteriidae), at three cultivation depths
}

\author{
Luis Felipe Freites ${ }^{l}$, Miguel Guevara ${ }^{1,4}$, Adrián Márquez ${ }^{1,2}$, Jormil Revilla ${ }^{1,2}$, Mariela Narváez y César Lodeiros ${ }^{1,3}$ \\ $\begin{array}{llllll}\text { (iD) } 0000-0002-6432-7366 & \text { (iD) } 0000-0002-1830-3822 & \text { (iD } 0000-0001-9122-6539 & \text { (iD } 0000-0002-9278-1080 & \text { (iD } 0000-0002-5062-5178 & \text { (iD } 0000-0001-9598-2235\end{array}$ \\ 1. Instituto Oceanográfico de Venezuela, Universidad de Oriente, Cumaná, Venezuela.mnarvaezruiz@gmail.com,lfreitesv@yahoo.es *Autor para \\ correspondencia. \\ 2. Escuela Superior Politécnica del Litoral (ESPOL), Centro Nacional de Acuicultura e Investigaciones Marinas (CENAIM), Guayaquil, Ecuador. \\ ajmm16@hotmail.com,jormilesteban@gmail.com \\ 3. Grupo de Investigación en Biología y Cultivo de Moluscos, Escuela de Acuicultura y Pesquerías, Facultad de Ciencias Veterinarias, Universidad \\ Técnica de Manabi, Bahía de Caráquez, Manabi, Ecuador. cesarlodeirosseijo@yahoo.es \\ 4. Instituto Superior de Formación Docente Salomé Ureña (Isfodosu), Santo Domingo, República Dominicana.miguevara2003@yahoo.es
}

\section{RESUMEN}

$\mathrm{S}$ e estudió la influencia de las variables ambientales asociadas con tres profundidades de agua (2, 6 y $10 \mathrm{~m})$ en el crecimiento de la concha, la masa seca de los tejidos blandos (MSTB) y la supervivencia de la ostra alada del Caribe Pteria colymbus (Roding, 1798).

La clorofila $a(\mathrm{Chl}-a)$, el oxígeno disuelto, la materia orgánica particulada (POM) y la temperatura se estudiaron a cada profundidad. Las ostras se colocaron en 135 cestas de plástico con cinco individuos en cada cesta. Se eligieron tres cestas en cada profundidad a intervalos mensuales para las mediciones de parámetros biométricos, bioincrustaciones y supervivencia. Al final del estudio, la masa seca de los individuos cultivados a $10 \mathrm{~m}$ fue significativamente menor (prueba no paramétrica de Kruskal-Wallis $\mathrm{KW}, \mathrm{P}<0,05$ ), mientras que los valores más altos de MSTB correspondientes a las ostras cultivadas a $2 \mathrm{~m}$ de profundidad. El análisis del componente principal mostró una relación inversa (temperatura) y directa (Chl- $a$ y POM) con la varianza observada en el MSTB. Teniendo en cuenta los resultados obtenidos en los rendimientos (crecimiento/supervivencia) de P. colymbus, recomendamos llevar a cabo su cultivo a profundidades de agua entre 2 y $6 \mathrm{~m}$.

PALABRAS CLAVE: bioincrustación, ambiente, profundidad, ostra, supervivencia.

\section{ABSTRACT}

$\mathrm{W}$ e studied the influence of environmental variables associated with three water depths $(2,6$ and $10 \mathrm{~m})$ on shell growth, soft tissues dry mass (STDM) and survival of the Caribbean winged oyster Pteria colymbus (Roding, 1798). chlorophyll- $a$ (Chl- $a$ ), dissolved oxygen, particulate organic matter (POM) and temperature were studied at each depth. Oysters were placed in 135 plastic baskets with five individuals in each basket. Three baskets at each depth were chosen at monthly intervals for measurements of biometric parameters, biofouling, and survival. At the end of the study, dry mass of the individuals grown at $10 \mathrm{~m}$ was significantly lower (Kruskal-Wallis non-parametric test KW, P $<0.05$ ) with the highest values of STDM corresponding to oysters cultivated at $2 \mathrm{~m}$ depth. The principal component analysis showed an inverse (temperature) and direct relationship (Chl- $a$ and POM) with respect to the variance observed in the STDM. Taking into account the results obtained in the yields (growth/survival) of $P$. colymbus we recommend carrying out their culture at water depths between 2 and $6 \mathrm{~m}$.

KEYWORDS: biofouling, environment, depth, oyster, survival. 


\section{INTRODUCCIÓN}

La ostra alada Pteria colymbus es un molusco bivalvo con una concha que se asemeja a unas alas, formada por una extensión de la charnela de ambas valvas. El tamaño de la concha de los individuos adultos puede alcanzar $60-80 \mathrm{~mm}$. Normalmente están fijadas a octocorales en la zona submareal desde Carolina del Norte hasta el sur de Brasil, a profundidades de agua entre 3 y 10 m (Díaz y Puyana, 1994; Lodeiros et al., 1999a). Las ostras aladas tienen un ciclo reproductivo casi continuo en aguas tropicales (Urban, 2001). Estudios relacionados con la ecofisiología y el cultivo de $P$. colymbus realizados en el Parque Nacional Natural Tayrona, Caribe colombiano (Urban, 2001; Urban y Riascos, 2001; Velasco y Barros, 2010) y el golfo de Cariaco, Venezuela (Lodeiros et al., 1999b; Marques et al., 2000; Mengual et al., 2011; Freites et al., 2017) indicaron que esta especie tiene un gran potencial de acuicultura.

Los bivalvos, como organismos poiquilotérmicos, son susceptibles a las fluctuaciones en las variables ambientales (Yukihira et al., 2000, 2006; Saxby, 2002). Se han observado relaciones entre la temperatura y la disponibilidad de alimentos (de origen fitoplancton y/o seston orgánico) con la tasa de crecimiento en especies de bivalvos de aguas templadas (Thompson y MacDonald, 1991; Pilditch y Grant, 1999; Freites et al., 2017). En general, una disminución en el crecimiento se asocia con un aumento de la profundidad debido a que las condiciones ambientales se vuelven menos favorables (Tomaru et al., 2002). Sin embargo, utilizando la profundidad de cultivo como una estrategia para generar variabilidad ambiental, se observó un bajo crecimiento cerca de la superficie (MacDonald y Bourne, 1989; Román et al., 1999), mientras que se informó un crecimiento reducido por debajo de una profundidad crítica, donde las condiciones de temperatura, la disponibilidad de alimentos y la turbidez a menudo exhiben un gradiente vertical subóptimo (Frechette y Daigle, 2002).

Se han demostrado diferencias significativas en el grosor de las perlas y la profundidad de cultivo en Pteria penguin (Kanjanachatree et al., 2003). Estas diferencias estaban relacionadas con el aumento en la disponibilidad de alimentos fitoplanctónicos a profundidades más bajas. Por lo tanto, comprender cómo las variables ambientales relacionadas con la profundidad del cultivo afectan el crecimiento de los bivalvos es fundamental para establecer estrategias de cultivo en áreas tropicales, particularmente en aquellas con alta variabilidad ambiental.

\section{INTRODUCTION}

The winged oyster Pteria colymbus is a bivalve mollusk characterized by a "winged" shell, formed by an extension of the hinge out of the shell. Shell size of the adult individuals can reach $60-80 \mathrm{~mm}$. normally they are attached to octocorals in the subtidal zone from North Carolina to southern Brazil, at water depths between 3 and 10 m (Díaz and Puyana, 1994; Lodeiros et al., 1999a). Winged oysters have a nearly continuous reproductive cycle in tropical waters (Urban, 2001). Studies related to ecophysiology and culture of P. colymbus conducted in the Parque Nacional Natural Tayrona, Colombian Caribe (Urban, 2001; Urban and Riascos, 2001; Velasco and Barros, 2010) and in the Gulf of Cariaco, Venezuela (Lodeiros et al., 1999b; Marques et al., 2000; Mengual et al., 2011; Freites et al., 2017) indicated this species has great aquaculture potential.

Bivalves, as poikilothermic organisms, are susceptible to fluctuations in environmental variables (Yukihira et al., 2000, 2006; Saxby, 2002). Relationships between temperature and food availability (phytoplankton origin and/or organic seston) with growth rate have been observed in bivalve species of temperate waters (Thompson and MacDonald, 1991; Pilditch and Grant, 1999; Freites et al., 2017). In general, a decrease in growth is associated with increasing depth due to environmental conditions becoming less favourable (Tomaru et al., 2002). However, using the culture depth as a strategy to generate environmental variability, low growth has been observed near the surface (MacDonald and Bourne, 1989; Román et al., 1999) while reduced growth has been reported below a critical depth where conditions of temperature, food availability and turbidity often exhibit a suboptimal vertical gradient (Frechette and Daigle, 2002).

Significant differences in the thickness of pearls in relation to culture depth have been demonstrated in the winged oyster Pteria penguin (Kanjanachatree et al., 2003), and that these differences were related to the increase in the availability of phytoplanktonic food at shallower depths. Therefore, understanding how environmental variables related to culture depth affect bivalve growth is critical to establish cultivation strategies in tropical areas, particularly in those with high environmental variability.

The Gulf of Cariaco, in northeastern Venezuela, displays marked variations in temperature and biomass phytoplankton throughout the water column due to the 
El golfo de Cariaco, en el noreste de Venezuela, muestra marcadas variaciones en la temperatura y la biomasa fitoplanctónica, en toda la columna de agua, debido al régimen de vientos alisios que provocan períodos de afloramiento (Muller-Karger et al., 1994, 2013). Debido a esta variabilidad ambiental, se han llevado a cabo estudios del cultivo a diferentes profundidades con vieiras con potencial para el cultivo, como Nodipecten nodosus y Euvola ziczac, que mostraron efectos significativos de la profundidad en el crecimiento y la reproducción (Freites et al., 1996; Lodeiros et al., 1998; Lodeiros y Himmelman, 2000). Es de esperar entonces que la variabilidad ambiental propia de la columna de agua del golfo de Cariaco probablemente también genere cambios en el crecimiento de otras especies, como la ostra alada $P$. colymbus. El presente estudio examina las influencias de la profundidad del cultivo y las variables ambientales asociadas al crecimiento de la ostra alada P. colymbus en cultivos suspendidos en el golfo de Cariaco, Venezuela.

\section{MATERIALES Y MÉTODOS}

Área de estudio

El estudio se realizó entre abril de 2013 y enero de 2014 en el sitio de Turpialito, golfo de Cariaco (Figura 1), noreste de Venezuela ( $10^{\circ} 27^{\prime} 30^{\prime \prime} \mathrm{N}, 64^{\circ} 01^{\prime} 52^{\prime}$ ' W). Los juveniles silvestres de $P$. colymbus fueron cosechados a mano en poblaciones naturales asentadas en redes de jaulas regime of trade winds that provoke periods of upwelling (Muller-Karger et al., 1994, 2013). This environmental variability has led to studies at different water depths with scallops of potential culture importance such as Nodipecten nodosus and Euvola ziczac that showed significant effects of depth on growth and reproduction (Freites et al., 1996; Lodeiros et al., 1998; Lodeiros and Himmelman, 2000). Here, the typical environmental variability in the column water in the Gulf of Cariaco would presumably also generate changes in the growth of other species, such as the winged oyster $P$. colymbus. The present study examines the influences of the culture depth and related environmental variables on growth of the winged oyster P. colymbus in suspended culture in the Gulf of Cariaco, Venezuela.

\section{MATERIALS AND METHODS}

\section{Study area}

The study was conducted from April 2013 to January 2014 at Turpialito site, Gulf of Cariaco (Figure $1)$, northeastern Venezuela ( $\left.10^{\circ} 27^{\prime} 30^{\prime \prime} \mathrm{N}, 64^{\circ} 01^{\prime} 52^{\prime \prime} \mathrm{W}\right)$. Wild P. colymbus juveniles were harvested by hand from natural populations settled in nets of floating cages used for fish culture in the Charagato Bay, Cubagua Island, Nueva Esparta State, Venezuela $\left(10^{\circ} 49^{\prime} 49,17^{\prime \prime} \mathrm{N}\right.$; $\left.64^{\circ} 09^{\prime} 40,42^{\prime \prime} \mathrm{O}\right)$. The pearl oysters were transferred to

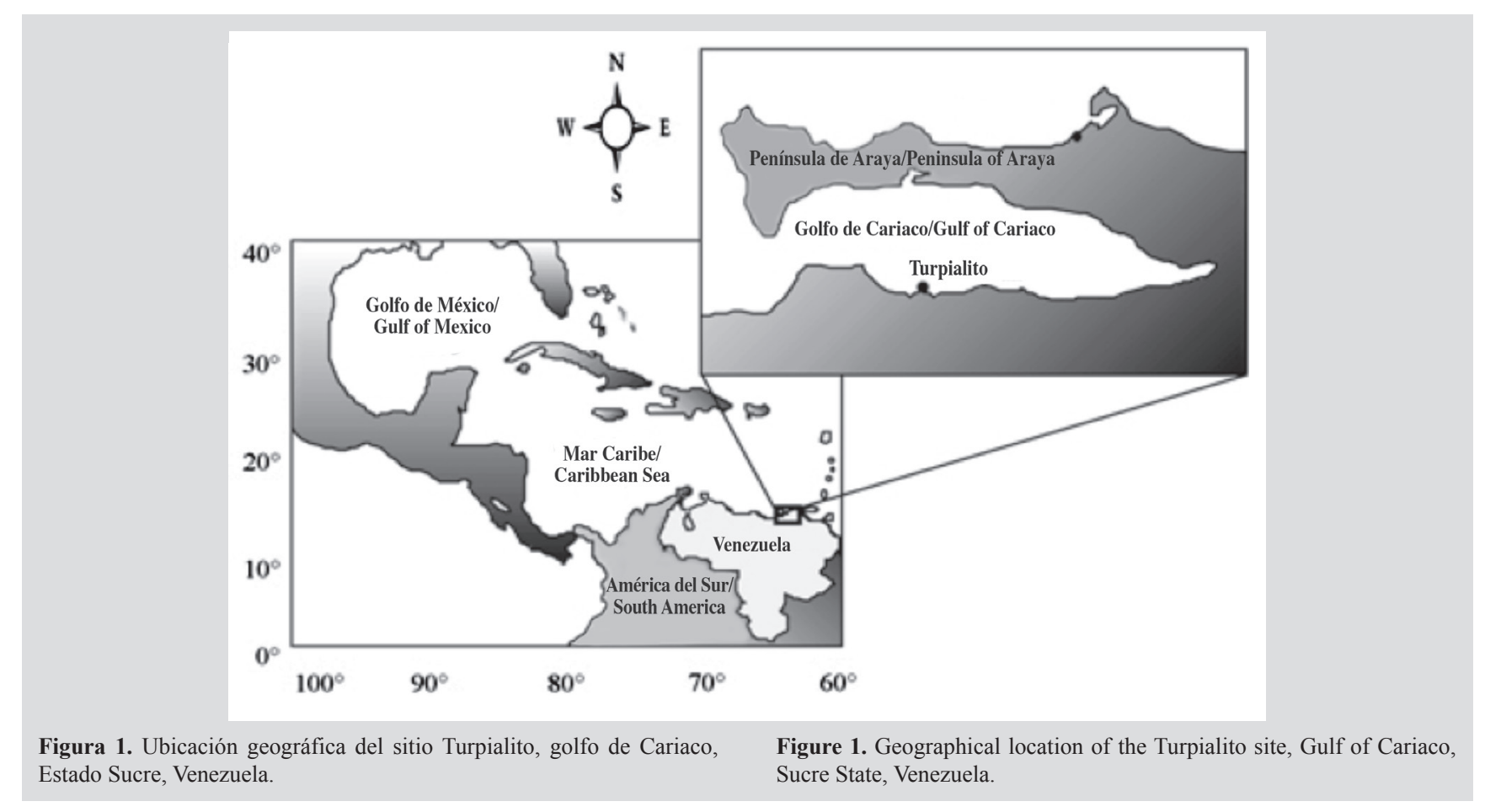


flotantes utilizadas para el cultivo de peces en la bahía Charagato, isla Cubagua, estado Nueva Esparta, Venezuela $\left(10^{\circ} 49^{\prime} 49,17^{\prime \prime} \mathrm{N} ; 64^{\circ} 09^{\prime} 40,42^{\prime \prime} \mathrm{O}\right)$. Las ostras aladas se transfirieron a la estación de investigación en Turpialito en contenedores aislados, empacados con capas de espuma humedecidas para mantener un ambiente fresco y limitar el estrés.

\section{Condiciones de crecimiento}

Las ostras aladas juveniles $(29,03 \pm 5,48 \mathrm{~mm}$ de altura de concha -talla dorsoventral-y $0,15 \pm 0,05 \mathrm{~g}$ de masa seca total de tejidos) fueron colocadas en cestas cilíndricas hechas de malla de plástico de malla de $2 \mathrm{~cm}$ y $25 \mathrm{~cm}$ de altura y $15 \mathrm{~cm}$ de diámetro, con una superficie total de $1531 \mathrm{~cm}^{2}$. Estas fueron suspendidas de una larga línea ubicada a $\sim 100$ $\mathrm{m}$ de la costa y $20 \mathrm{~m}$ de profundidad, mientras que las cestas se desplegaron a $2 \mathrm{~m}$ de profundidad, durante una semana, para aclimatarse antes de los ensayos. El experimento comenzó colocando 30 cestas experimentales más 5 cestas de sustitución para cada una a una de las profundidades de cultivo de 2, 6 y 10 m (Figura 2).

Se colocaron cestas de sustitución para mantener la densidad inicial durante todo el período experimental. Al comienzo del experimento, la altura de la concha no varió significativamente entre las ostras que serían colocadas a las tresprofundidades(Kruskal-Wallis; $\mathrm{P}=0,935$ ). Mensualmente, se recolectaban tres canastas de cada profundidad de cultivo para determinar el número de individuos vivos y muertos. En el resto de las canastas experimentales, las ostras muertas fueron contadas y reemplazadas por especímenes vivos para mantener la densidad de población inicial y las canastas fueron limpiadas para eliminar las bio-incrustaciones. La altura del eje de la concha se determinó con un calibrador digital $( \pm 0,01 \mathrm{~mm})$. Las incrustaciones en las conchas de las ostras se extrajeron cuidadosamente y se pesaron después del secado. Se retiraron los tejidos blandos de cada ostra usando equipo de disección y se separaron para determinar la masa seca de tejidos y conchas. Estos componentes se secaron en un horno $\left(60{ }^{\circ} \mathrm{C}, 48 \mathrm{~h}\right)$ para obtener valores de masa seca utilizando una balanza analítica $( \pm 0,001 \mathrm{~g})$.

El número de ostras vivas se registró en cada canasta y la tasa de supervivencia total (\%) se calculó en cada muestreo de la siguiente manera:

\section{Tasa de supervivencia $=(\mathrm{Nt} / \mathrm{No}) \times 100$}

Donde,

Nt es el número de ostras vivas en el momento $t$

No es el número de ostras vivas al comienzo del experimento a research station in Turpialito in insulated containers packed with moistened foam layers to maintain a cool environment and limit stress.

\section{Growth conditions}

Juveniles oysters $(29.03 \pm 5.48 \mathrm{~mm}$ shell height (dorso-ventral axis) and $0.15 \pm 0.05 \mathrm{~g}$ total tissues dry mass) were placed in cylindrical baskets made of $2 \mathrm{~cm}$ mesh size plastic net and $25 \mathrm{~cm}$ in height and $15 \mathrm{~cm}$ in diameter, with a total surface of $1531 \mathrm{~cm}^{2}$. They were suspended from a long line located at $\sim 100 \mathrm{~m}$ offshore and $20 \mathrm{~m}$ depth, while baskets were deployed at $2 \mathrm{~m}$ depth for one week for acclimatization prior to the trials. The experiment began by placing 30 experimental baskets plus 5 substitution baskets by each at 2, 6 and $10 \mathrm{~m}$ culture depth (Figure 2).

Substitution baskets were placed to maintain the initial density throughout experimental period. Shell height did not significantly vary among the oysters at the three depths at the start of the experiment (Kruskal-Wallis; $\mathrm{P}=0.935$ ). Monthly, three baskets were collected from each culture depth to determine the number of living and dead individuals. In the rest of the experimental baskets, the dead oysters were counted and replaced by live specimens to maintain the initial population density and the baskets were cleaned to eliminate the biofouling. Shell axis height was determined with a digital caliper $( \pm 0.01 \mathrm{~mm})$. The fouling on the oyster shells was carefully extracted and weighed after drying. Soft tissues were removed from each oyster using dissecting equipment and separated to determine the dry mass of tissues and shell. These components were dried in an oven $\left(60^{\circ} \mathrm{C}, 48 \mathrm{~h}\right)$ to obtain dry mass values using an analytical balance $( \pm 0.001 \mathrm{~g})$.

The number of live oysters was recorded in each basket and total survival rate (\%) was calculated at each sampling time as follows:

$$
\text { Survival rate }=(\mathrm{Nt} / \mathrm{No}) \times 100
$$

Where,

$\mathrm{N}_{t}$ is the number of live oysters at time $\mathrm{t}$

No is the number of live oysters at the beginning of the experiment 


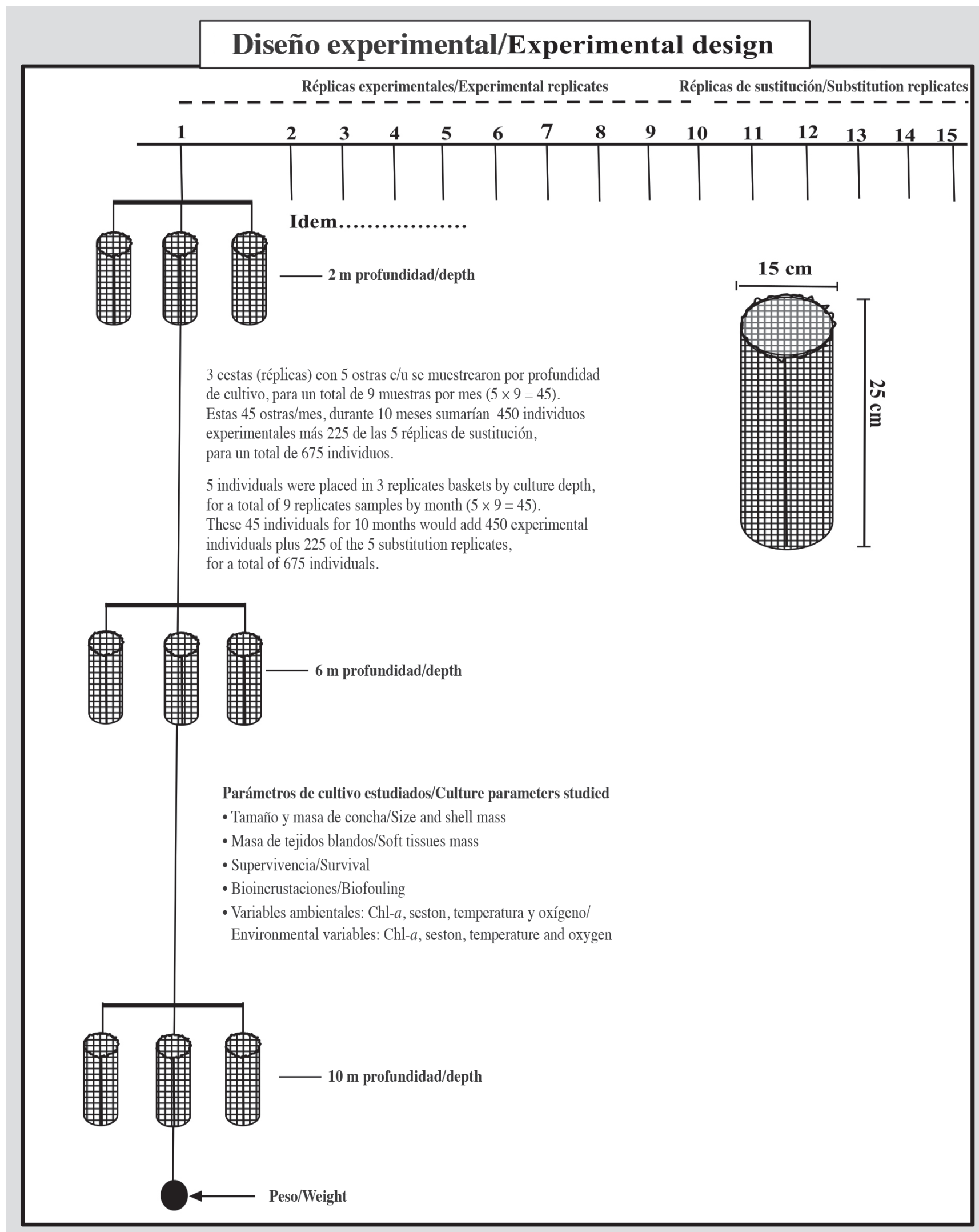




\section{Variables ambientales}

La temperatura del agua se controló continuamente a cada profundidad de agua utilizando termógrafos electrónicos (Sealog-Vemco) con una periodicidad de $30 \mathrm{~min}$. Se tomaron muestras de agua cada quince días usando una botella Niskin. Se tomó cuidadosamente una alícuota de cada muestra para evitar burbujas de aire en la determinación de oxígeno disuelto utilizando el método Winkler, dentro de las $6 \mathrm{~h}$ posteriores al muestreo (límite de detección 0,07 $\mathrm{mg} \mathrm{L}^{-1}$ ). Las muestras de agua se transportaron al laboratorio en un recipiente de plástico opaco para la determinación de la salinidad con un refractómetro Atago (1 UPS de precisión). Las muestras de biomasa del fitoplancton, determinadas como clorofila $a(\mathrm{Chl}-a)$, y el seston total se transfirieron a una botella de plástico opaca.Todas las muestras fueron transportadas al laboratorio en contenedores isotérmicos. Posteriormente, dos réplicas de $1 \mathrm{~L}$ se prefiltraron $(153 \mu \mathrm{m})$ para eliminar partículas grandes y zooplancton y luego se usaron para determinar Chl- $a$ y el seston total para cada una de las profundidades de agua. Las muestras de agua de mar se tamizaron en filtros $\mathrm{GF} / \mathrm{F}$ de $0,7 \mu \mathrm{m}$ prequemados y pesados $\left(450{ }^{\circ} \mathrm{C}\right.$ durante $4 \mathrm{~h}$ ), y se enjuagaron con formiato de amonio isotónico $(0,5 \mathrm{M})$. El seston total se estableció después de secar los filtros a una masa constante obtenida a $60{ }^{\circ} \mathrm{C}$ (48 h). La materia orgánica particulada (POM) correspondió a la pérdida de peso después de su combustión a $450{ }^{\circ} \mathrm{C}$ durante 4 h en una mufla. La abundancia de fitoplancton se estimó determinando la concentración de Chl- $a$ por el método espectrofotométrico siguiendo a Strickland y Parsons (1972).

\section{Análisis estadístico}

El análisis estadístico general sobre la altura y masa de la concha, la masa de los tejidos blandos y de las bioincrustaciones, y la supervivencia de las ostras se analizó utilizando la prueba no paramétrica de Kruskal-Wallis (KW), expresada gráficamente en gráficos de caja y bigotes. Este gráfico muestra la mediana, el rango y la distribución de los datos, además de servir como un ANOVA gráfico y no paramétrico. Los datos biométricos de las ostras aladas y la bioincrustación se transformaron en $\log 10$ y el porcentaje de supervivencia se transformó en arcocoseno (Sokal y Rohlf, 1979). Se utilizó una probabilidad de 0,05 para los análisis estadísticos.

Para establecer la relación entre las variables ambientales en cada profundidad de cultivo estudiada, se realizó un análisis de componentes principales (ACP) basado en la matriz de correlación. Las variables consideradas

\section{Environmental variables}

Water temperature was monitored continuously at each water depth using electronic thermographs (SealogVemco) with a periodicity of $30 \mathrm{~min}$. Water samples were taken fortnightly using a Niskin bottle. One aliquot of each sample was carefully taken to avoid air bubbles for the determination of dissolved oxygen using the Winkler method within $6 \mathrm{~h}$ of sampling (detection limit $0.07 \mathrm{mg} \mathrm{L}^{-1}$ ). Water samples were transported to the onshore laboratory in an opaque plastic container for salinity determination with a refractometer Atago (one PSU precision). Salinity was determined with an Atago refractometer. Samples for phytoplankton biomass, determined as chlorophyll- $a(\mathrm{Chl}-a)$, and total seston were transferred on board to an opaque plastic bottle. All samples were transported to the laboratory in isothermal containers. Thereafter, two $1 \mathrm{~L}$ replicates were pre-filtered $(153 \mu \mathrm{m})$ to remove large particulate matter and zooplankton and then used to determine Chl- $a$ and total particulate matter for each water depth. Seawater samples were filtered on precombusted and weighed GF/F $0.7 \mu \mathrm{m}$ filters $\left(450{ }^{\circ} \mathrm{C}\right.$ for $4 \mathrm{~h}$ ) and rinsed with isotonic ammonium formate $(0.5 \mathrm{M})$. Total dry mass was established after drying the filters to constant mass obtained at $60{ }^{\circ} \mathrm{C}(48 \mathrm{~h})$. Particulate organic matter (POM) corresponded to the weight loss after ignition at $450{ }^{\circ} \mathrm{C}$ for $4 \mathrm{~h}$ in a muffle furnace. The phytoplankton abundance was estimated by determining the concentration of Chl- $a$ by the spectrophotometric method following Strickland and Parsons (1972).

\section{Statistical analysis}

Overall statistical analysis on shell height and mass, tissues and biofouling mass, and survival of oysters were analyzed using the non-parametric Kruskal-Wallis test (KW), expressed graphically in box and whisker plots. The box-and-whisker plot shows the median, range, distribution of the data as well as serving as a graphical, nonparametric ANOVA. Biometric data of winged oysters and biofouling were transformed into $\log 10$ and survival percentage was transformed to arccosine (Sokal and Rohlf, 1979). A probability of 0.05 was used for statistical analyses.

To establish the relationship between the environmental variables at each cultivated depth studied, a Principal Component Analysis was performed based on the correlation matrix. The variables considered were temperature, STDM, Chl- $a$ and particulate organic matter, 
fueron temperatura, MSTB, Chl- $a$ y POM, que ocurrieron durante todo el período experimental (Chatfield y Collins, 1980; Clarke y Warwick, 2001). A este respecto, es necesario mencionar que no se consideró el oxígeno disuelto porque no mostró una correlación previa con ninguna de las variables utilizadas en el análisis.

\section{RESULTADOS}

\section{Tamaño de la concha}

La tasa de crecimiento en la altura de la concha de la ostra mostró un incremento progresivo en las tres profundidades de cultivo (Figura 3a), que fue más evidente desde abril hasta finales de julio de 2013. Posteriormente, las tasas de crecimiento fueron más lentas pero sostenidas, mostrando una pendiente más baja hasta enero de 2014, cuando alcanzaron alturas las conchas de $69,76 \pm 0,46,68,19 \pm 1,71 \mathrm{y}$ $65,38 \pm 1,58 \mathrm{~mm}$ a 2,6 y $10 \mathrm{~m}$, respectivamente, mostrando una relación estrecha, pero inversamente proporcional entre el crecimiento y la profundidad del cultivo. Sin embargo, al final del período de cultivo, no se observaron diferencias significativas (KW, $\mathrm{P}>0,05)$ de los individuos cultivados en las tres profundidades (Figura $3 b$ ).

\section{Masa de tejidos blandos}

En mayo, junio y julio hubo un marcado aumento en la masa de las ostras cultivadas a las tres profundidades, pero con menor magnitud en las ostras cultivadas a $10 \mathrm{~m}$ (Figura 3c). Estas tendencias fueron revertidas con una marcada caída durante agosto por las ostras cultivadas a 2, 6 y $10 \mathrm{~m}$. Posteriormente, hubo una recuperación casi sostenida de la masa de tejidos blandos. Al final del experimento, los individuos tenían una masa seca de tejidos blandos a $2 \mathrm{~m}$ $(1,67 \pm 0,14 \mathrm{~g}), 6 \mathrm{~m}(1,78 \pm 0,15 \mathrm{~g})$ y $10 \mathrm{~m}(1,55 \pm 0,10 \mathrm{~g})$, siendo la masa seca de los individuos cultivados a $10 \mathrm{~m}$ significativamente más baja $(\mathrm{KW}, \mathrm{P}<0,05)$ que la de los cultivados a 2 y 6 m (Figura $3 \mathrm{~d}$ ).

Masa de la concha

Similar al patrón de crecimiento descrito en la altura de la concha de la ostra, la masa de la concha mostró un crecimiento sostenido durante todo el período de estudio (Figura 3e). Al final del estudio, los individuos tenían una masa seca máxima cultivada a 2, 6 y $10 \mathrm{~m}$ de $8,29 \pm 0,60$, $8,44 \pm 0,40,7,48 \pm 0,67 \mathrm{~g}$, respectivamente. Durante el período experimental, solo se observaron diferencias significativas $(\mathrm{KW}, \mathrm{P}<0,05)$ entre los individuos cultivados a $2 \mathrm{~m}$ y $10 \mathrm{~m}$ (Figura 3f). which occurred during the entire experimental period (Chatfield and Collins, 1980; Clarke and Warwick, 2001) In this regard, it is necessary to mention that dissolved oxygen was not considered because it did not show a previous correlation with any of the variables used in the analysis.

\section{RESULTS}

Shell size

The growth rate in the height shell axis of the oyster showed a progressive increment at three culture depths (Figure 3a), being more evident from April to the end of July 2013. Thereafter, the growth rates were slower but sustained, showing a lower slope until January 2014, when they attained shell heights of $69.76 \pm 0.46$, $68.19 \pm 1.71$ and $65.38 \pm 1.58 \mathrm{~mm}$ at 2,6 and $10 \mathrm{~m}$, respectively, showing a narrow but inversely proportional relationship between growth and culture depth. However, at the end of the cultivation period, no significant differences $(\mathrm{KW}, \mathrm{P}>0.05$ ) of the individuals grown in the three culture depths were observed (Figure $3 b$ ).

\section{Soft tissue mass}

In May, June and July there was a marked increase in oyster mass grown at the three depths, but with lesser magnitude in the oysters grown a $10 \mathrm{~m}$ (Figure 3c). These trends were then reversed, with a marked fall during August by the oysters grown at 2, 6 and $10 \mathrm{~m}$. Thereafter, there was an almost sustained recovery of the soft tissue mass. At the end of the experiment, individuals had a dry mass of soft tissues at $2 \mathrm{~m}(1.67 \pm 0.14 \mathrm{~g}), 6 \mathrm{~m}(1.78 \pm 0.15 \mathrm{~g})$ and $10 \mathrm{~m}(1.55 \pm 0.10 \mathrm{~g})$, being the dry mass of the individuals grown at $10 \mathrm{~m}$ significantly lower $(\mathrm{KW}, \mathrm{P}<0.05)$, than those grown at 2 and $6 \mathrm{~m}$ (Figure $3 \mathrm{~d}$ ).

\section{Shell mass}

Similar to the described pattern of growth in shell height of oysters, the mass of the shell showed sustained growth throughout the study period (Figure 3e). At the end of the study, individuals had a maximum dry mass cultivated at 2, 6 and $10 \mathrm{~m}$ of $8.29 \pm 0.60,8.44 \pm 0.40$, $7.48 \pm 0.67 \mathrm{~g}$, respectively. Over the experimental period, significant differences $(\mathrm{KW}, \mathrm{P}<0.05)$ were only observed between individuals grown at $2 \mathrm{~m}$ with respect to those cultivated at $10 \mathrm{~m}$ (Figure $3 \mathrm{f}$ ). 


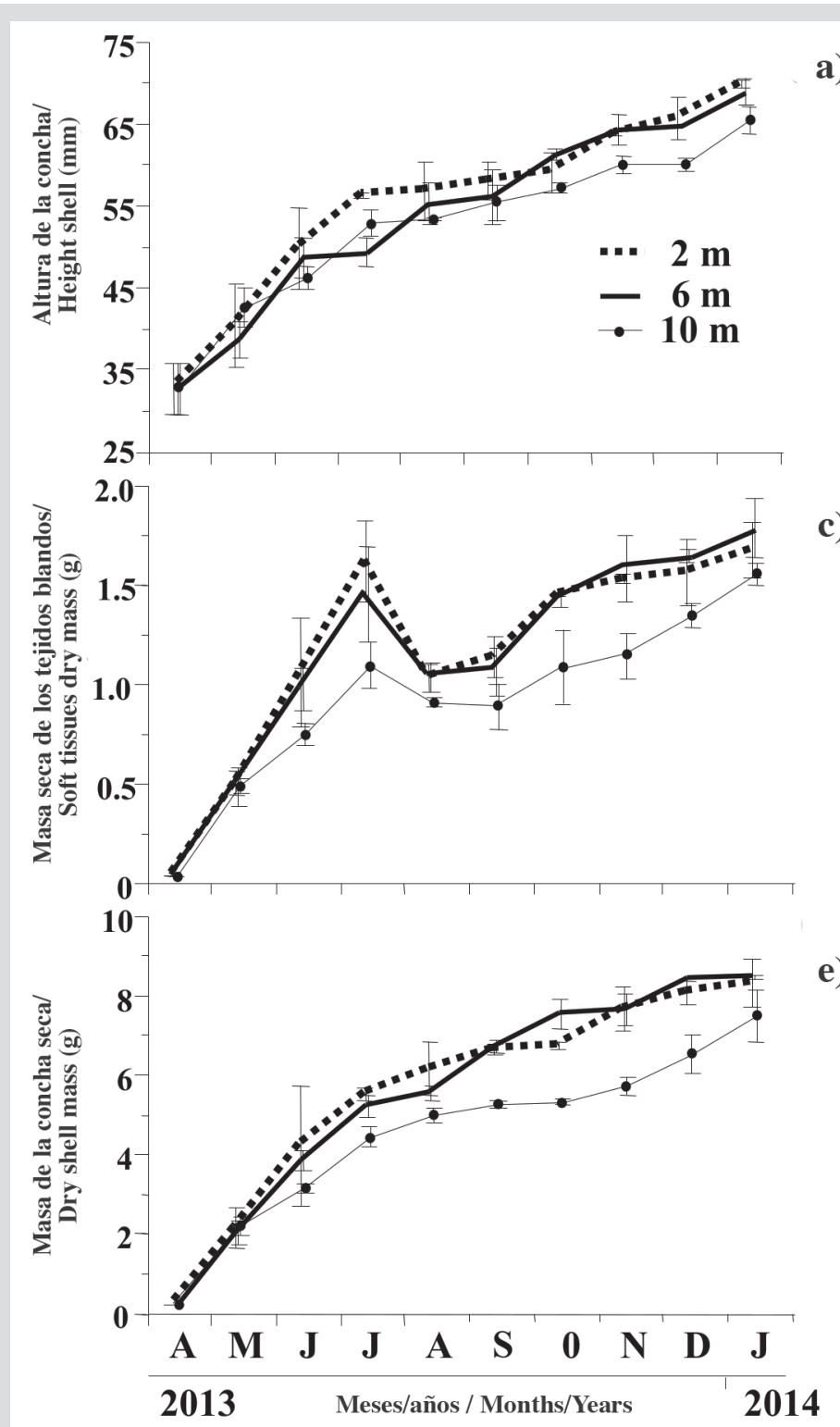

a)

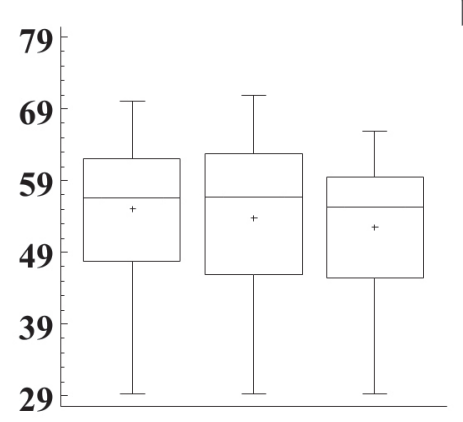

b)

c)

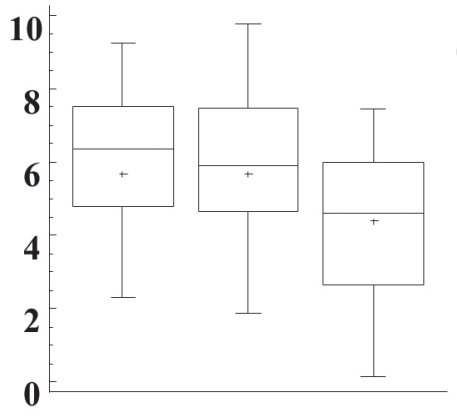

d)

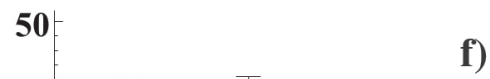

)

)

\section{)}

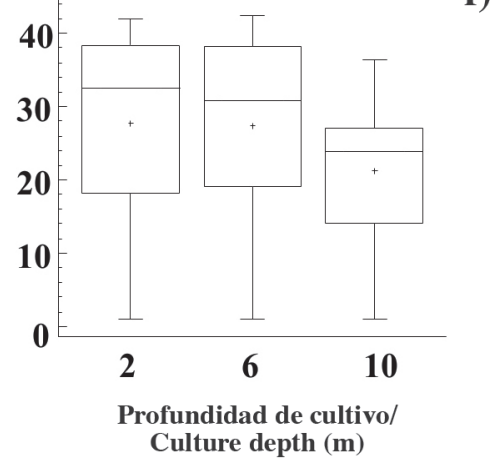

Figura 3. Variación de: a) altura de la concha, c) masa seca de los tejidos blandos y e) masa de la concha de $P$. colymbus cultivada a las diferentes profundidades estudiadas y sus respectivas figuras de prueba Kruskal Wallis b), d) y f). Los símbolos y las barras de error representan los valores mensuales medios más la desviación estándar, respectivamente. En las gráficas de caja y bigotes, la línea horizontal central de la caja es la mediana de los datos, la parte superior e inferior de la caja son los percentiles (cuartiles) de $25 \%$ y $75 \%$, y los extremos de los bigotes son los 5 y $95 \%$ percentiles. La muesca en el cuadro es el intervalo de confianza de $95 \%$ de la mediana. Cuando las muescas entre las cajas no se superponen, las medianas se consideran significativamente diferentes (Briceño y Boyer, 2010).
Figure 3. Variation of: a) height shell, c) soft tissues dry mass and e) shell mass of $P$. colymbus cultivated at the different depths studied and its respective Kruskal Wallis test figures b), d), f). Symbols and error bars represent mean monthly values plus the standard deviation, respectively. In box and whisker plots, the center horizontal line of the box is the median of the data, the top and bottom of the box are the $25 \%$ and $75 \%$ percentiles (quartiles), and the ends of the whiskers are the 5 and $95 \%$ percentiles. The notch in the box is the $95 \%$ confidence interval of the median. When notches between boxes do not overlap, the medians are considered significantly different (Briceño and Boyer, 2010). 
Masa de las bioincrustaciones

La masa seca de las bioincrustaciones fijada en los individuos cultivados a las 3 profundidades mostró un aumento similar y moderado hasta julio (Figura 4a), y luego un aumento mayor y sostenido hasta diciembre y una disminución en enero. Después del período experimental, la acumulación de bioincrustación en los individuos no fue significativa $(\mathrm{KW}, \mathrm{P}>0,05)$ entre las tres profundidades (Figura 4b). Esto se atribuyó, en parte, a la alta variación de masa de bioincrustación de las réplicas, en cada profundidad de cultivo.

\section{Biofouling mass}

Dry mass of the biofouling settled on the individuals grown at the 3 depths showed a similar and moderate increase until July (Figure 4a), and then a greater and sustained increase until December and decline in January. At the conclusion of the experimental period, biofouling accumulation on individuals was not significantly $(\mathrm{KW}, \mathrm{P}>0.05$ ) between the three depths (Figure 4b). This was attributed in part to the high biofouling mass variation from replicates at each culture depth.
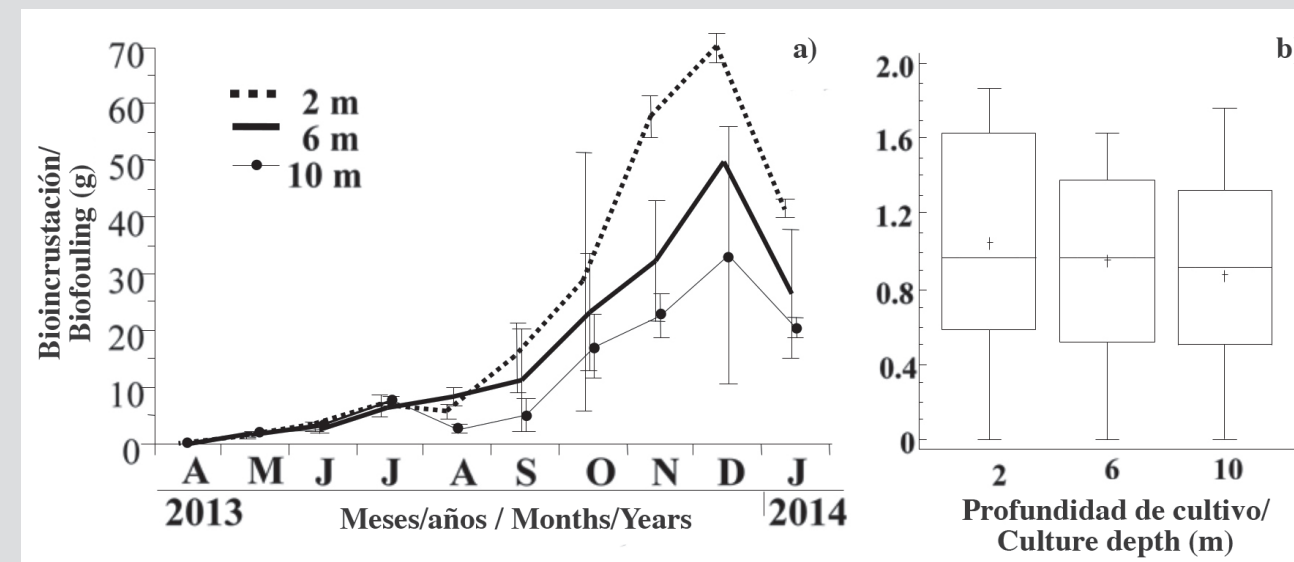

b)

Figura 4. a) Variación de la masa seca de las bioincrustaciones fijadas sobre $P$. colymbus, cultivadas a las diferentes profundidades estudiadas, y b) sus respectivas pruebas de Kruskal Wallis. Los símbolos y las barras de error representan los valores mensuales medios más la desviación estándar, respectivamente.
Figure 4. a) Variation of the fixed biofouling dry mass of $P$. colymbus, cultivated at the different depths studied, and b) its respective Kruskal Wallis test. Symbols and error bars represent mean monthly values plus the standard deviation, respectively.

\section{Supervivencia}

La supervivencia fue de $100 \%$ en individuos cultivados a profundidades de 2 y $6 \mathrm{~m}$ hasta noviembre, y por encima de 80 y 93,3 \% al final del período experimental, respectivamente (Figura 5a). Por el contrario, los individuos que crecieron a $10 \mathrm{~m}$ tuvieron una caída en la supervivencia desde octubre hasta el final del período de estudio, con un porcentaje final ligeramente superior al $40 \%$. En consecuencia, al final del período experimental se observó una supervivencia significativamente mayor $(\mathrm{KW}, \mathrm{P}<0,05)$ de individuos cultivados a $6 \mathrm{~m}$ (Figura 5b).

\section{Variables ambientales}

La concentración de oxígeno disuelto en las tres profundidades experimentales varió entre 6 y $9 \mathrm{mg} \mathrm{L}^{-1}$ durante todo el período de estudio (Figura 6a). Se observaron dos períodos de marcadas caídas, particularmente a $10 \mathrm{~m}$ (abril-mayo/2013, agosto-septiembre/2013) con valores más bajos de $\approx 6,5 \mathrm{mg} \mathrm{L}^{-1}$, y dos períodos con aumentos a las

\section{Survival}

Survival was $100 \%$ in individuals grown at depths of 2 and $6 \mathrm{~m}$ until November, and above 80 and $93.3 \%$ respectively, at the end of the experimental period (Figure 5a). In contrast, individuals grown at $10 \mathrm{~m}$ had a fall in the survival from October until the end of the study period, with a final percentage of slightly above $40 \%$. In consequence, at the end of the experimental period was observed a significantly higher survival $(\mathrm{KW}, \mathrm{P}<0.05)$ of individuals grown at $6 \mathrm{~m}$ than $10 \mathrm{~m}$ (Figure $5 \mathrm{~b}$ ).

\section{Environmental variables}

Dissolved oxygen concentration at the three experimental depths varied between 6 to $9 \mathrm{mg} \mathrm{L}^{-1}$ throughout the study period (Figure 6a). Two periods of sharp decline were observed, particularly at $10 \mathrm{~m}$ (April-May/2013, August-September/2013) with lowest values of $\approx 6.5 \mathrm{mg} \mathrm{L}^{-1}$, and two periods with increases at three depths (July-August/2013, December/2013- 


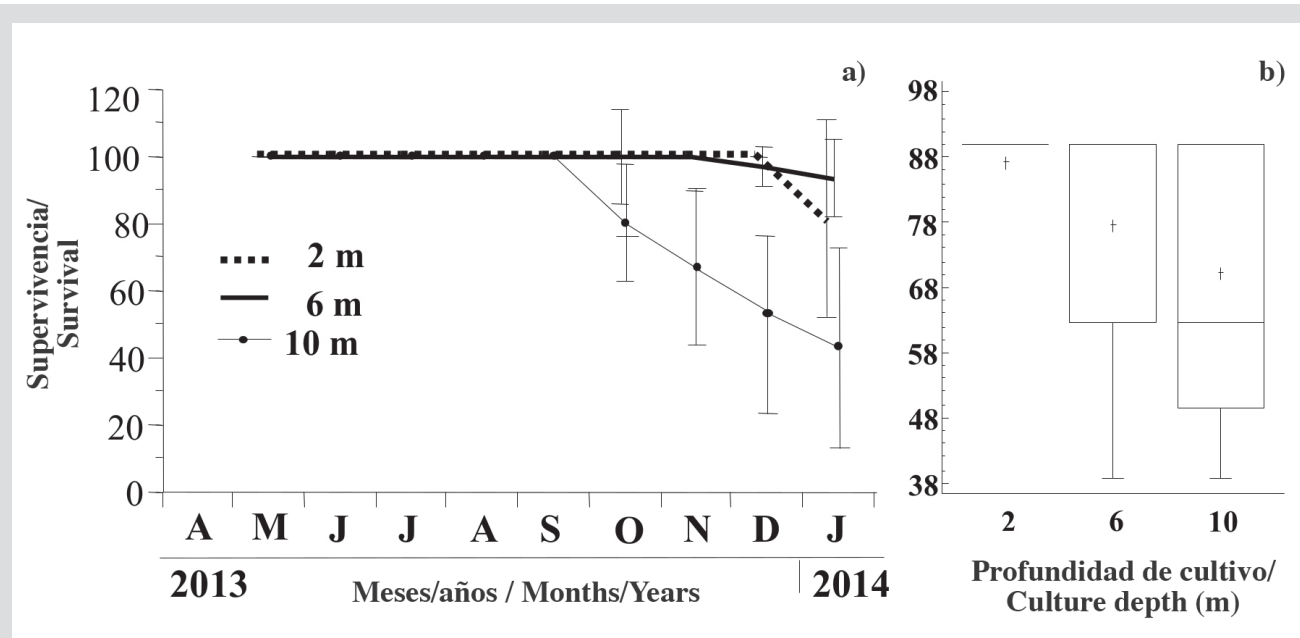

Figura 5. a) Supervivencia de $P$. colymbus cultivado a las diferentes profundidades estudiadas, y b) sus respectivas figuras de la prueba de Kruskal Wallis. Los símbolos y las barras de error representan los valores mensuales medios más la desviación estándar, respectivamente.
Figure 5. a) Survival of $P$. colymbus cultivated at the different depths studied, and b) its respective Kruskal Wallis test figures. Symbols and error bars represent mean monthly values plus the standard deviation, respectively. tres profundidades (julio-agosto/2013, diciembre/2013enero/2014), donde el oxígeno disuelto alcanzó los valores más altos $\left(\approx 8,5 \mathrm{mg} \mathrm{L}^{-1}\right)$. El oxígeno disuelto mostró diferencias significativas $(\mathrm{P}<0,05)$ entre tres profundidades (Figura 6b), con concentraciones más altas a profundidades más bajas.

La temperatura mostró una clara tendencia al alza desde abril hasta septiembre de 2013, donde los valores máximos excedieron los $28{ }^{\circ} \mathrm{C}$ en las tres profundidades (Figura 6c). Posteriormente, se observó una disminución marcada y sostenida hasta el final del estudio, con valores de alrededor de $23{ }^{\circ} \mathrm{C}$ en las tres profundidades de cultivo. No se observaron diferencias significativas $(\mathrm{P}>0,05)$ entre la profundidad y la temperatura durante el período de estudio (Figura 6d).

En general, las curvas de la materia orgánica particulada (POM) observada en cada profundidad mostraron tendencias similares a las descritas para el oxígeno disuelto, alcanzando valores mínimos en julio de 2013 (Figura 6e), especialmente a $10 \mathrm{~m}\left(1,17 \mathrm{mg} \mathrm{L}^{-1}\right)$, y un aumento general hasta septiembre de 2013 de alrededor de $2,2 \mathrm{mg} \mathrm{L}^{-1}$. Finalmente, en enero de 2014, la materia orgánica alcanzó valores máximos, especialmente a profundidades de 2 y $6 \mathrm{~m}$ (3,67 y $2,78 \mathrm{mg} \mathrm{L}^{-1}$, respectivamente). No se observaron diferencias significativas $(\mathrm{P}>0,05)$ entre las concentraciones de materia orgánica en las tres profundidades de cultivo (Figura 6f). La Chl- $a$ aumentó en cada profundidad de agua desde abril hasta julio de 2013 con valores entre 4,8 y 3,2 $\mathrm{gg} \mathrm{L}^{-1}$ (Figura 6g), con las concentraciones más altas a $2 \mathrm{~m}$, comenzando en agosto
January/2014), where dissolved oxygen reached highest values $\left(\approx 8.5 \mathrm{mg} \mathrm{L}^{-1}\right)$. Dissolved oxygen showed significant differences $(\mathrm{P}<0.05)$ between three depths (Figure $6 \mathrm{~b})$, with higher concentrations at lower depths.

Temperature showed a clear increasing trend from April 2013 until September 2013 where maximum values exceeded $28^{\circ} \mathrm{C}$ at the three depths (Figure 6c). Thereafter, a marked and sustained decline was observed until the end of the study, with values around $23{ }^{\circ} \mathrm{C}$ in the three culture depths. No significant differences $(\mathrm{P}>0.05)$ were observed between the depth and temperature over the study period (Figure 6e).

In general, the trends in particulate organic matter (POM) at each depth showed similar trends as those described for the dissolved oxygen, reaching minimum values in July 2013 (Figure 6e), especially at $10 \mathrm{~m}$ (1.17 $\left.\mathrm{mg} \mathrm{L}^{-1}\right)$, and a general increase until September 2013 to around $2.2 \mathrm{mg} \mathrm{L}^{-1}$. Finally, in January 2014, organic matter reached maximum values, especially at depths of 2 and $6 \mathrm{~m}$ (3.67 and $2.78 \mathrm{mg} \mathrm{L}^{-1}$, respectively). No significant differences $(\mathrm{P}>0.05)$ were observed between organic matter concentrations at the three culture depths (Figure 6f). Chl- $a$ was elevated for each water depth from AprilJuly 2013 with values between 4.8 and $3.2 \mu \mathrm{g} \mathrm{L}^{-1}$ (Figure $6 \mathrm{~g})$, with the highest concentrations at $2 \mathrm{~m}$, beginning in August and continuing through November, where Chl- $a$ concentrations declined sharply between 0.2 to $1.2 \mu \mathrm{g}$. Thereafter, Chl- $a$ peaked from December 2013 until January 2014, with concentrations between 5.4 and 

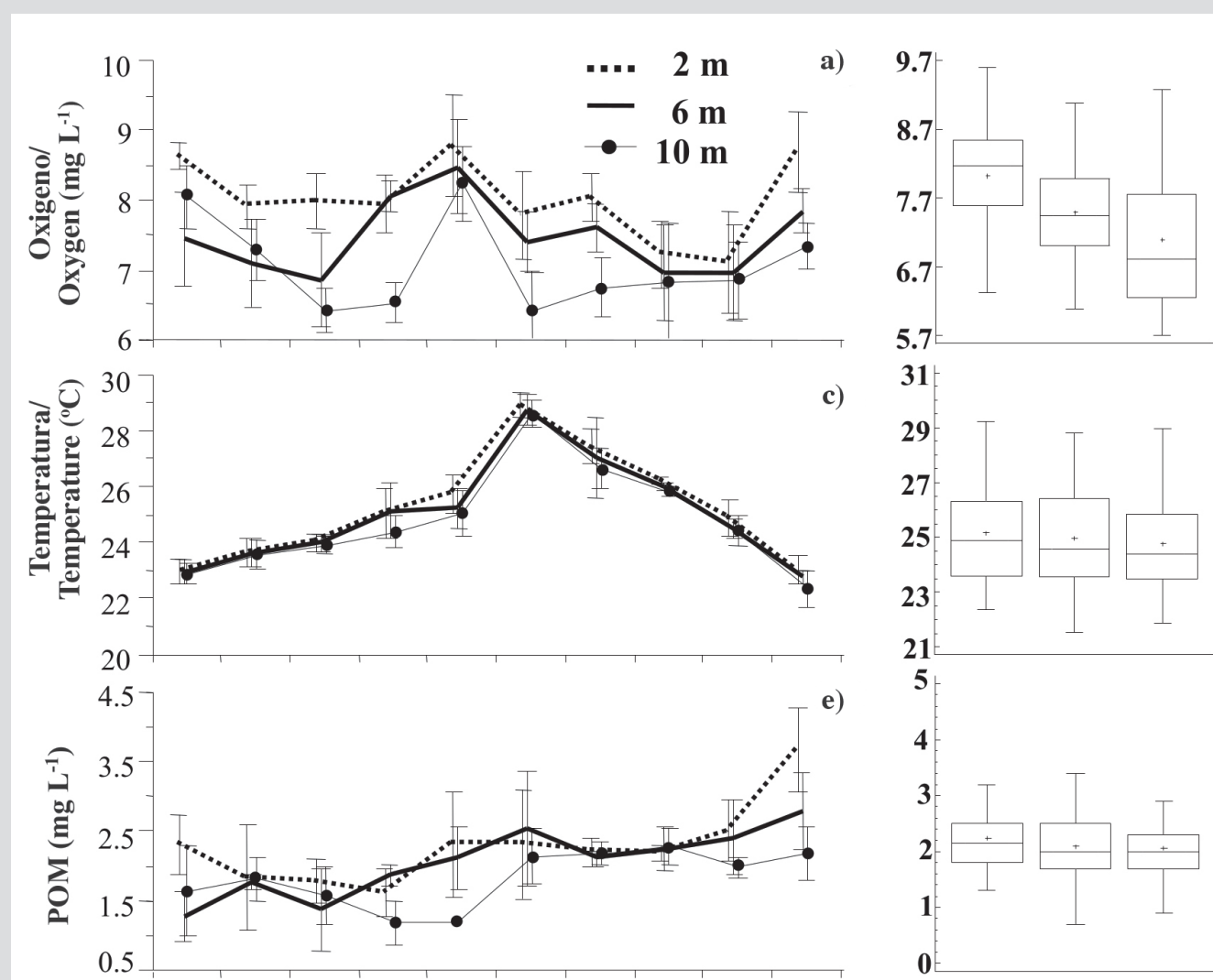

b)
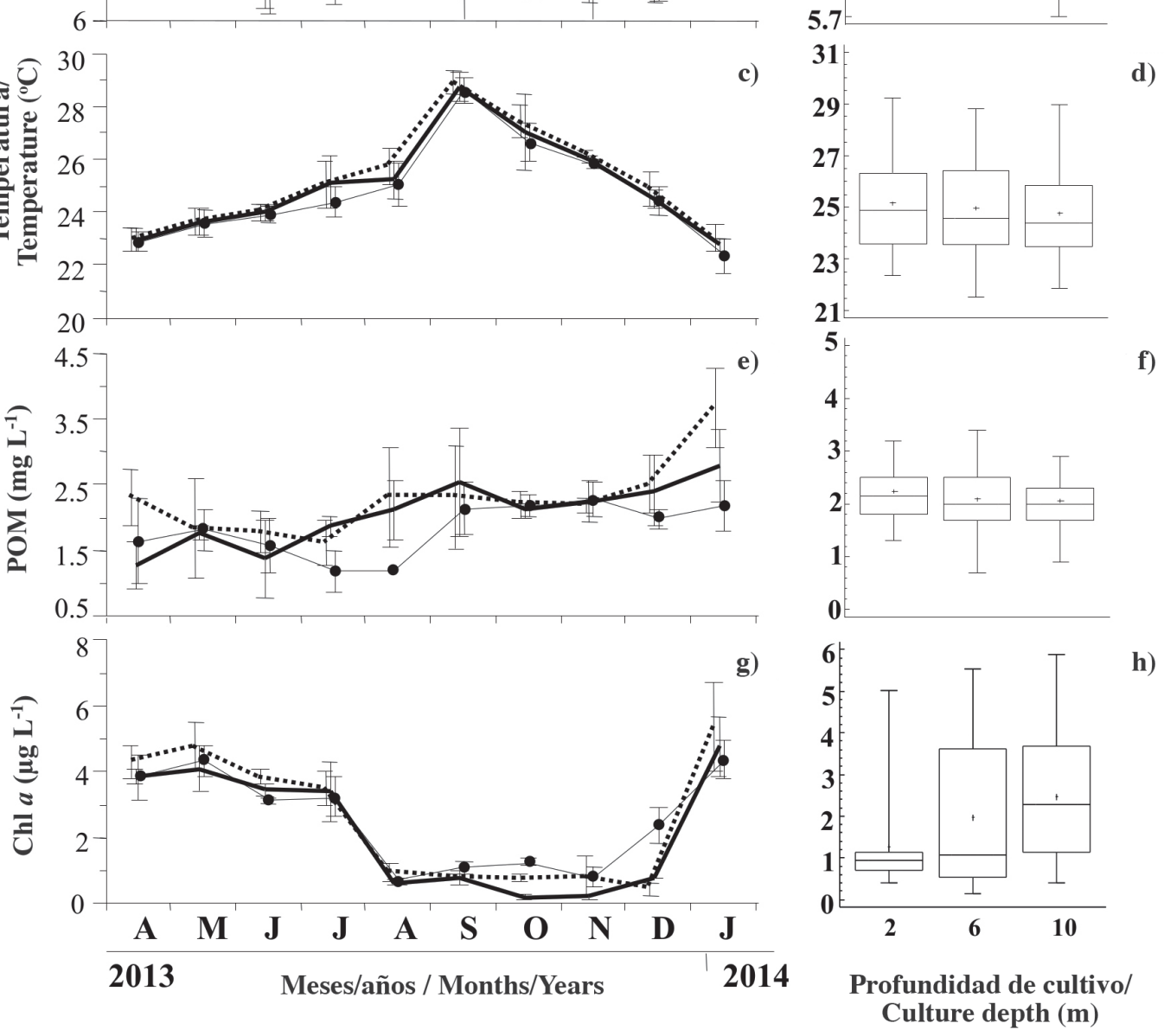

Figura 6. Variación de las variables ambientales: a) oxígeno disuelto; c) temperatura; e) POM y g) Chl- $a$, a las diferentes profundidades, estudiadas y sus respectivas cifras de prueba de Kruskal Wallis b), d), f), h). Los símbolos y las barras de error representan valores mensuales medios más la desviación estándar, respectivamente.
Figure 6. Variation of environmental variables: a) dissolved oxygen; c) temperature; e) POM and g) Chl- $a$, at the different depths studied and its respective Kruskal Wallis test figures b), d), f), h). Symbols and error bars represent mean monthly values plus the standard deviation, respectively. y continuando hasta noviembre, donde las concentraciones de Chl- $a$ disminuyeron bruscamente entre 0,2 a $1,2 \mu \mathrm{g}$. Posteriormente, la Chl- $a$ alcanzó su punto máximo desde diciembre de 2013 hasta enero de 2014, con concentraciones entre 5,4 y $4,3 \mu \mathrm{g} \mathrm{L}^{-1}$, respectivamente, con los valores más altos a $2 \mathrm{~m}$. Durante el estudio, Chl- $a$ mostró diferencias significativas entre profundidades ( $\mathrm{KW}, \mathrm{P}<0,05)$, con una relación inversa con la profundidad del agua, influenciada por las concentraciones más altas observadas entre septiembre y diciembre a $10 \mathrm{~m}$ (Figura 6h).
$4.3 \mu \mathrm{g} \mathrm{L}{ }^{-1}$, respectively, and the highest values at $2 \mathrm{~m}$. Over the study, Chl- $a$ showed significant differences between depths ( KW, $\mathrm{P}<0.05$ ), with an inverse relation with water depth, influenced by the higher concentrations observed between September and December at $10 \mathrm{~m}$ (Figure 6h). 
Influencia de las variables ambientales en la masa del tejido

El análisis de ACP resultó en ecuaciones que muestran una relación entre las diferentes variables estudiadas (MSTB, Chl- $a$, POM y temperatura), de la siguiente manera:

a) $\mathbf{2} \mathbf{m}=0,375 * \mathrm{MSTB}+0,670 *$ Chl- $a-0,329 *$ Temperatura $+0,550 * \mathrm{POM}$

b) $6 \mathbf{m}=0,052 * \mathrm{MSTB}+0,700 *$ Chl- $a-0,709 *$ Temperatura $+0,076 * \mathrm{POM}$

c) $\mathbf{1 0} \mathbf{~ m}=0,477 * \mathrm{MSTB}+0,594^{*}$ Chl- $a-0,619 *$ Temperatura $+0,191 * \mathrm{POM}$

La ecuación general que tiene en cuenta toda la variabilidad en las tres profundidades de cultivo es:

d) 2-10 $\mathbf{m}=0,253^{*} \mathrm{MSTB}+0,662 *$ Chl- $a-0,634 *$ Temperatura $+0,309 * \mathrm{POM}$

El ACP entre las diferentes variables estudiadas mostró que los dos primeros componentes explicaron un $77 \%$ (2 m), $90 \%(6 \mathrm{~m}), 76 \%(10 \mathrm{~m})$ y $73 \%$ $(2-10 \mathrm{~m})$ de la varianza observada, lo que indica que estas son representaciones gráficas aceptables (Tabla 1). En todas 2, 6 y 10 m fueron Chl- $a$, MSTB y POM con una correlación positiva, todas ellas inversamente relacionadas con la temperatura. Además, la relación descrita previamente para cada profundidad de cultivo fue similar a la obtenida en el intervalo de columna de agua de 2-10 m (d).

Tabla 1. Porcentaje de varianza explicado por dos componentes de los datos de PCA correspondientes a MSTB de las ostras y a variables ambientales como partículas de materia orgánica (POM, ) Chl- $a$ y temperatura. las ecuaciones, las variables que contribuyen a la varianza a

Influence of environmental variables on the tissues mass

The PCA analysis resulted in equations that show a relationship between the different variables studied (STDM, Chl- $a$, POM and temperature), as follows:

a) $2 \mathbf{m}=0.375 * \mathrm{STDM}+0.670 *$

Chl- $a-0.329 *$ Temperature $+0.550 * \mathrm{POM}$

b) $6 \mathbf{m}=0.052 * \mathrm{STDM}+0.700 *$

Chl- $a-0.709 *$ Temperature $+0.076 * \mathrm{POM}$

c) $10 \mathrm{~m}=0.477 * \mathrm{STDM}+0.594 *$

Chl- $a-0.619 *$ Temperature $+0.191 * \mathrm{POM}$

The general equation that takes into account all variability in the three culture depth is:

d) $\mathbf{2 - 1 0} \mathbf{~ m}=0.253 * \mathrm{STDM}+0.662 *$

Chl- $a-0.634 *$ Temperature $+0.309 * \mathrm{POM}$

PCA between the different variables studied showed that the first two components explained a $77 \%$ $(2 \mathrm{~m}), 90 \%(6 \mathrm{~m}), 76 \%(10 \mathrm{~m})$ and $73 \%(2-10 \mathrm{~m})$ of the variance observed, indicating that these are acceptable graphical representations (Table 1). In all equations, the variables that contribute to variance at 2, 6 and $10 \mathrm{~m}$ were Chl- $a$, STDM and POM with a positive correlation, all being inversely related to the temperature. Moreover, the relationship described previously for each culture depth was similar to the obtained at the $2-10 \mathrm{~m}$ water column interval (d).

Table 1. Percentage of variance explained by two components of the PCA data corresponding to STDM of the oyster and environmental variables such as particle organic matter (POM), Chl- $a$, and temperature.

Profundidad de cultivo/Culture depth

\begin{tabular}{|c|c|c|c|c|c|}
\hline Componentes/Components & $2 \mathrm{~m}$ & $6 \mathrm{~m}$ & $10 \mathrm{~m}$ & $4-10 \mathrm{~m}$ \\
\hline $\mathbf{1}$ & 48.942 & 56.105 & 46.727 & 29.443 \\
\hline $\mathbf{2}$ & 28.402 & 33.973 & 29.728 & 31.938 \\
\hline Varianza acumulada/Cumulate variance & 77.344 & 90.078 & 76.455 & 73.381 \\
\hline
\end{tabular}




\section{DISCUSIÓN}

La disponibilidad y calidad del alimento pueden considerarse factores importantes que afectan los procesos fisiológicos relacionados con el crecimiento (Bayne y Newel, 1983). Las partículas de comida suspendidas varían en calidad y cantidad para los bivalvos y, en general, forman parte del seston, que es una mezcla compleja de organismos pelágicos (principalmente fitoplancton) y detritos suspendidos, frecuentemente asociados positivamente con la temperatura (Navarro y Thompson, 1995; Cranford y Hill, 1999; Hawkins et al., 2001). En este estudio, la biomasa de fitoplancton (Chl- $a$ ) mostró los valores más altos en el período de abril-mayo de 2013 y enero de 2014 (1,85-2,78 $\left.\mu \mathrm{g} \mathrm{L}^{-1}\right)$ cuando la temperatura fue más baja, mientras que se observaron bajas concentraciones $\left(0,79 \mu \mathrm{g} \mathrm{L}^{-1}\right)$ en septiembre, durante la temperatura más alta. Según Lodeiros y Himmelman (2000), la relación inversa entre la temperatura y la abundancia de fitoplancton en la mayoría de los estudios concuerda con los períodos observados de afloramiento costero y estratificación del agua establecidos en el golfo de Cariaco. Los valores de Chl- $a$ mostrados por Mengual et al. (2011) en las cercanías de la bahía de Mochima también mostraron un patrón inverso con la temperatura, es decir, la Chl- $a$ estaba por debajo de $1 \mathrm{mg} \mathrm{L}^{-1}$ cuando se registró la temperatura máxima. Sin embargo, las tendencias del POM no mostraron un patrón definido, con valores generalmente superiores a $1,5 \mathrm{mg} \mathrm{L}^{-1}$. Estos valores son similares a los registrados por Prieto et al. (2001) y Villarroel et al. (2004) en el golfo de Cariaco. Las concentraciones más altas de POM observadas en los últimos tres meses de estudio (2-3,7 $\left.\mathrm{mg} \mathrm{L}^{-1}\right)$ coincidieron con un aumento en la masa de tejidos blandos. En este sentido, Cranford y Grant (1990) informaron que, aunque el fitoplancton es una fuente importante de alimento para los bivalvos, los detritos orgánicos pueden contribuir a la absorción de energía en períodos en los que las concentraciones de fitoplancton son demasiado escasas para satisfacer las demandas de energía. Resultados similares han resaltado la importancia de la concentración de POM en ensayos comparativos para evaluar diferentes ubicaciones del cultivo de algunas especies de bivalvos, como Corbicula japonica (Kasay y Nakata, 2005), Chlamys islandica (Blicher et al., 2010), Crassostrea gigas (Beninger et al., 2008), Perna canaliculus (Gardner y Thompson, 2001), Chlamys farreri (Zhang et al., 2010), Nodipecten nodosus (Freites et al., 2003) y Moerella rutile (Kang et al., 2006).

\section{DISCUSSION}

The availability and quality of food can be considered an important factor that affects the physiological processes linked to growth (Bayne and Newel, 1983). Suspended food particles for bivalves vary in quality and quantity and, in general, are composed of seston which itself is a complex mixture of pelagic organisms (principally phytoplankton) and suspended detritus, frequently positively associated with temperature (Navarro and Thompson, 1995; Cranford and Hill, 1999; Hawkins et al., 2001). In the study phytoplankton biomass (Chl- $a$ ) showed the highest values in the period AprilMay 2013 and January 2014 when the temperature was lower (1.85-2.78 $\mu \mathrm{g} \mathrm{L}^{-1}$ ), while low concentrations were observed during the highest temperature in September $\left(0.79 \mu \mathrm{g} \mathrm{L}^{-1}\right)$. According to Lodeiros and Himmelman (2000), the inverse relationship between temperature and phytoplankton abundance in most studies agrees with the observed periods of coastal upwelling and water stratification established in the Gulf of Cariaco. Chl- $a$ values reported by Mengual et al. (2011) in the nearby of Mochima Bay generally showed an inverse pattern to temperature as well, that is, Chl- $a$ was below $1 \mathrm{mg} \mathrm{L}^{-1}$ when maximum temperature was recorded. However, the trends of POM showed no definite pattern, with values generally above $1.5 \mathrm{mg} \mathrm{L}^{-1}$. These values are similar to those reported by Prieto et al. (2001) and Villarroel et al. (2004) in the Gulf of Cariaco. Higher concentrations of POM observed in the last three months of study $\left(2-3.7 \mathrm{mg} \mathrm{L}^{-1}\right)$ coincided with an increase in soft tissue mass. Therefore, Cranford and Grant (1990) reported that, although phytoplankton is an important food source for bivalves, organic detritus can contribute to energy uptake in periods when phytoplankton concentrations are too scarce to satisfy energy demands. Similar results have highlighted the importance of POM concentration in comparative trials to test for differences between culture locations of some bivalve species, such as: Corbicula japonica (Kasay and Nakata, 2005), Chlamys islandica (Blicher et al., 2010), Crassostrea gigas (Beninger et al., 2008), Perna canaliculus (Gardner and Thompson, 2001), Chlamys farreri (Zhang et al., 2010), Nodipecten nodosus (Freites et al., 2003) and Moerella rutile (Kang et al., 2006).

In this study, the different equations (A, B, C) obtained from the PCA showed that the variables that participated in the variance observed were POM, Chl- $a$, temperature and STDM of the oysters. These results agree 
En este estudio, las diferentes ecuaciones (A, $\mathrm{B}, \mathrm{C})$ obtenidas de la PCA mostraron que las variables que participaron en la varianza observada fueron POM, Chl- $a$, temperatura y MSTB de las ostras. Estos resultados concuerdan con otros estudios realizados en el golfo de Cariaco, donde se demostró que la influencia de las variables ambientales asociadas con la profundidad del cultivo puede influir en el crecimiento de algunas especies de bivalvos marinos (Lodeiros et al., 1998; Acosta et al., 2009; García et al., 2016).

Las longitudes de concha alcanzadas en diez meses por la ostra alada cultivada a tres profundidades fueron $69,76 \mathrm{~mm}(2 \mathrm{~m}), 67,19 \mathrm{~mm}(6 \mathrm{~m})$ y $65,38 \mathrm{~mm}(10 \mathrm{~m})$ mientras que su aumento promedio relativo alcanzó 118 , 112 y $104 \%$, respectivamente (altura inicial $\approx 32 \mathrm{~mm}$ ). Este crecimiento difiere notablemente de los resultados obtenidos por Gaytan-Mondragon et al. (1993), quienes encontraron un aumento de $\approx 144 \%$ en la altura dorsalventral de $P$. sterna en 10 meses. Un incremento de tamaño similar para $P$. colymbus se obtuvo en 8 meses $(\approx 94 \%)$ (Lodeiros et al., 1999b).

Nuestros resultados implican la factibilidad de cultivo de las ostras aladas en el sitio de Turpialito, donde Lodeiros et al. (2002) también informaron aumentos del $100 \%$ en el crecimiento de la concha de la ostra perla Pinctada imbricata. Los valores encontrados en este estudio para la longitud de la concha fueron más altos que los mostrados por Mengual et al. (2011), quienes cultivaron P. colymbus en la bahía de Mochima y mostraron un aumento menor en el crecimiento del eje longitudinal del $68 \%$, con un tamaño y un período de cultivo inicial similares. Seis meses después del período experimental, los individuos obtuvieron un incremento de la altura de la concha de 58,54 y $52 \%$ a profundidades de 2,6 y 10 $\mathrm{m}$, respectivamente. Estos valores son más altos que el incremento (41\%) observado durante el mismo tiempo de cultivo en la ostra alada Pteria hirundo (tamaño inicial de 39,40 mm) cultivada en Brasil a 1-2 m de profundidad (Albuquerque et al., 2012).

Los individuos muertos solo se observaron en el último muestreo, lo que puede estar relacionado con la presencia de dos especies de gasterópodos de la familia Rannellidae (Linatella caudata y Monoplex pilearis). Estos caracoles también son responsables de la mortalidad de las ostras de perla comercialmente importantes Pinctada martensis (Zhou y Pan, 1999), P. margaritifera (Aji, 2011) y P. imbricata (Malavé et al., 2012). with other studies carried out in the Gulf of Cariaco, where it was demonstrated that the influence of the environmental variables associated with the culture depth can influence the growth of some species of marine bivalves (Lodeiros et al., 1998; Acosta et al., 2009; García et al., 2016).

The shell lengths attained in ten months by the winged oyster grown at three depths were $69.76 \mathrm{~mm}(2 \mathrm{~m})$, $67.19 \mathrm{~mm}(6 \mathrm{~m})$ and $65.38 \mathrm{~mm}(10 \mathrm{~m})$, while their relative average increase reached 118,112 and $104 \%$, respectively (initial height $\approx 32 \mathrm{~mm}$ ). This growth differs markedly from the results obtained by Gaytan-Mondragon et al. (1993) who found an increase of $\approx 144 \%$ in the dorsalventral height of $P$. sterna in 10 months. A similar size increment was obtained for $P$. colymbus (Lodeiros et al., 1999 b) in 8 months $(\approx 94 \%)$.

Our results imply feasibility of cultivation of winged oyster at the Turpialito site, where Lodeiros et al. (2002) also reported increases of $100 \%$ in the shell growth of the pearl oyster Pinctada imbricata. The values found for the length axis in this study were higher than those showed by Mengual et al. (2011), who cultivated $P$. colymbus in Mochima Bay and showed a smaller growth increase of length axis of $68 \%$, with a similar size and initial culture period. Six months into the experimental period, individuals obtained a shell height increment of 58, 54 and $52 \%$ at depths of 2, 6 and $10 \mathrm{~m}$, respectively. These values are higher than the increment $(41 \%)$ observed over the same culture time in the winged oyster Pteria hirundo (initial size of $39.40 \mathrm{~mm}$ ) cultured in Brazil at 1-2 m depth (Albuquerque et al., 2012).

Dead individuals were only observed in the last sampling, which may be related to the presence of two gastropods species of the Rannellidae family (Linatella caudata and Monoplex pilearis). These snails are also responsible for the mortality of commercially important pearl oysters Pinctada martensis (Zhou and Pan, 1999), P. margaritifera (Aji, 2011) and P. imbricata (Malavé et al., 2012).

Decreases in soft tissue mass in the AugustSeptember period for the oysters grown at the three depths could be related to spawning, as shown by Marquez et al. (2000) who observed a peak in the spat recruitment of $P$. colymbus at the same site and annual period of the present study. However, from October until the end of the culture period, the tissue mass increased in individuals grown at the three culture depths, which is consistent with a previous 
Las disminuciones en la masa de tejidos blandos observados en el período de agosto a septiembre para las ostras cultivadas a las tres profundidades podrían estar relacionadas con el desove, puesto que Márquez et al. (2000) observaron un pico en el reclutamiento de $P$. colymbus en el mismo sitio y período anual del presente estudio. Sin embargo, desde octubre hasta el final del período de cultivo, la masa de tejido aumentó en individuos cultivados en las tres profundidades de cultivo, lo que es consistente con el desarrollo de la gónada antes del pico de desove principal mostrado en diciembre por Márquez et al. (2000).

Al final del período experimental, nuestros resultados mostraron un mayor crecimiento de la biomasa de tejidos blandos de individuos cultivados en aguas poco profundas $(2$ y $6 \mathrm{~m})$ que en aguas profundas $(10 \mathrm{~m})$. Esto concuerda con los resultados de Smitasiri et al. (1994) y Kanjanachatree et al. (2003), quienes registraron un mayor crecimiento de individuos de Pteria penguin cultivados en aguas poco profundas (2-5 $\mathrm{m}$ de profundidad) que en las profundas ( $15 \mathrm{~m}$ de profundidad). Estos autores atribuyeron esta diferencia a una mayor disponibilidad de alimentos a poca profundidad. Sims (1994) y Lee et al. (2008) también observaron un mayor crecimiento de juveniles de Pinctada margaritifera y $P$. maxima, respectivamente, cuando se cultivaron en aguas poco profundas. Teniendo en cuenta los resultados obtenidos en el rendimiento (crecimiento/ supervivencia) de los individuos de la ostra alada $P$. colymbus, recomendamos llevar a cabo su cultivo entre 2 y $6 \mathrm{~m}$ de profundidad.

\section{AGRADECIMIENTOS}

El estudio fue financiado con subvenciones de proyectos UDO-FONACIT 2011000344 Estación Hidrobiológica de Turpialito del Instituto Oceanográfico de Venezuela de la Universidad de Oriente como Centro de Monitoreo Ambiental y Producción de Semillas de Moluscos Bivalvos. Los autores agradecen a Andrew Dale por mejorar el idioma inglés. gonadal mass prior to the main spawning peak shown by Marquez et al. (2000) in December.

At the end of the experimental period, our results showed a higher growth of the soft tissue biomass of individuals grown in shallower waters (2 and $6 \mathrm{~m}$ ) than in deep waters $(10 \mathrm{~m})$. This agrees with the results by Smitasiri et al. (1994) and Kanjanachatree et al. (2003) who reported a higher growth of Pteria penguin individuals cultivated in shallow waters (2-5 m depth) than in deep ones (15 m depth). These authors attributed this difference to higher food availability at the shallow depth. Furthermore, Sims (1994) and Lee et al. (2008) also observed higher growth of Pinctada margaritifera and P. maxima juveniles, respectively, when cultivated in shallow waters. Taking into account the results obtained in the performance (growth/survival) of the individuals of the winged oyster $P$. colymbus, we recommend carrying out their culture between 2 and $6 \mathrm{~m}$ water depth.

\section{ACKNOWLEDGEMENTS}

The study was funded with grants from projects UDO-FONACIT 2011000344 Estación Hidrobiológica de Turpialito del Instituto Oceanográfico de Venezuela de la Universidad de Oriente como Centro de Monitoreo Ambiental y Producción de Semillas de Moluscos Bivalvos. The authors thank Andrew Dale for improving the English-language. 


\section{BIBLIOGRAFÍA/LITERATURE CITED}

Acosta, V., C. Lodeiros, A. Prieto, M. Glem e Y Natera. 2009. Efecto de la profundidad sobre el crecimiento de los mejillones Perna perna y Perna viridis (Bivalvia: Mytilidae) en cultivo suspendido en el golfo de Cariaco, Venezuela. Zoot. Trop., 27(3): 315-328.

Aji, L.P. 2011. An overview of the method, management, problem, and their solution in the pearl oyster (Pinctada margaritifera) culture. J. Coastal Develop., 14(3): 181-190.

Albuquerque, M.C.P., R. Alves, A. Zanandrea, J. Ferreira, C. Melo and A. Magalhães. 2012. Growth and survival of the pearl oyster Pteria hirundo (L., 1758) in an intermediate stage of culture in Santa Catarina, Brazil. Braz. J. Biol., 72: 175-180.

Bayne, B. and R. Newell. 1983. Physiological energetics of marine mollusc: 407-515. In: Salenium, A. and K. Wilbur (Eds.). The Mollusca. Academics Press. New York.

Beninger, P.G., A. Valdizan, P. Decottignies and B. Cognie. 2008. Impact of seston characteristics on qualitative particle selection sites and efficiencies in the pseudolamellibranch bivalve Crassostrea gigas. J. Exp. Mar. Biol. Ecol., 360: 9-14.

Blicher, M.E., S. Rysgaard and M.K. Sejr. 2010. Seasonal growth variation in Chlamys islandica (Bivalvia) from sub-Arctic Greenland is linked to food availability and temperature. Mar. Ecol. Prog. Ser., 407: 71-86.

Briceño, H.O. and J.N. Boyer. 2010. Climatic controls on phytoplankton biomass in a sub-tropical estuary, Florida Bay, USA. Estuar. Coasts, $33:$ 541-553.

Chatfield, C. and A. Collins. 1980. Introduction to multivariate analysis. Chapman and Hall, London.

Clarke, K. and R. Warwick. 2001. Change in marine communities: An approach to statistical analysis and interpretation. PRIMER-E Ltd., Plymouth. 82 p.

Cranford, P.J. and J. Grant. 1990. Particle clearance and absorption of phytoplankton and detritus by the sea scallop Placopecten magellanicus (Gemelin). J. Exp. Mar. Biol. Ecol., 137: 105-121.

Cranford, P.J. and P.S. Hill. 1999. Seasonal variation in food utilization by the suspension-feeding bivalve mollusks Mytilus edulis and Placopecten magellanicus. Mar. Ecol. Prog. Ser., 190: 223-239.

Díaz, J.M. y M. Puyana, 1994. Moluscos del Caribe colombiano. Un catálogo ilustrado. Colciencias Fundación Natura-INVEMAR. Presencia, Bogotá. 291 p.

Frechette, M. and G. Daigle. 2002. Growth, survival and fluctuating asymmetry of Iceland scallops in a test of density-dependent growth in a natural bed. J. Exp. Mar. Biol. Ecol., 270: 73-91.

Freites, L., A. Vélez y L. Hurtado. 1996. Crecimiento y producción secundaria de Euvola (Pecten) ziczac (L), en cultivo suspendido a tres profundidades. Bol. Inst. Oceanog. Venez., 35(1 y 2): 17-26.

Freites, L., C. Lodeiros, N. Narváez, G. Estrella and J.M.F. Babarro, 2003. Growth and survival of the scallop Lyropecten (=Nodipecten) nodosus (L., 1758) in suspended culture in the Cariaco Gulf (Venezuela), during a non-upwelling period. Aquacult. Res., 34: 709-718.

Freites, L., M. Rojas, A.W. Dale, A. Márquez, J. Revilla, C. Lodeiros and L. Tróccoli. 2017. Influence of environmental variables during seasonal upwelling on the growth of the winged oyster Pteria colymbus in a tropical ecosystem. Aquacult. Intern., 25: 1653-1666.

García, M., C. Lodeiros, L. Freites, H. Córdova and J. Babarro. 2016. Comparative performance of the mussels Perna perna and Perna viridis, cultivate at four different depths. Braz. J. Oceanog., 64(3): 249-262.

Gardner, J.P.A. and R.J. Thompson, 2001. Naturally low seston concentration and the net energy balance of the greenshell mussel (Perna canaliculus) at Island Bay, Cook Strait, New Zealand. NZ J. Mar. Freshwater Res., 35: 457-468.

Gaytan-Mondragon, I., C. Cáceres-Martínez and M. Tobias-Sánchez. 1993. Growth of the pearl oysters Pinctada mazatlanica and Pteria sterna in different culture structures at La Paz Bay, Baja California Sur, Mexico. J. World Aquacult. Soc., 24(4): 541-546.

Hawkins, A.J.S., J.G. Fang, P.L. Pascoe, J.H. Zhang, X.L. Zhang and M.Y. Zhu. 2001. Modelling short-term responsive adjustments in particle clearance rate among bivalve suspension-feeders: separate unimodal models of seston volume and composition in the scallop Chlamys farreri. J. Exp. Mar. Biol. Ecol., 261: 61-73.

Kanjanachatree, K., K. Piyathamrongrut and N. Inthonjaroen. 2003. Effects of sea depths and sizes of winged pearl oysters (Pteria penguin) on pearl culture. Songklanakarin J. Sci. Techn., 25(5): 659-671.

Kasai, A. and A. Nakata, 2005. Utilization of terrestrial organic matter by the bivalve Corbicula japonica estimated from stable isotope analysis. Fish. Sci., 71: 151-158.

Lee, A.M., A. Williams and P.C. Southgate. 2008. Modelling and comparison of growth of the silverlip pearl oyster Pinctada maxima (Mollusca: Pteriidae) cultured in West Papua, Indonesia. Mar. Freshwater Res., 59: 22-31. 
Lodeiros C., B. Marín y A. Prieto. 1999a. Catálogo de moluscos de las costas nororientales de Venezuela. Clase Bivalvia. Apudons, Caracas. 103 p.

Lodeiros, C. and J.H. Himmelman. 2000. Identification of factors affecting growth and survival of the tropical scallop Euvola (Pecten) ziczac in the golfo de Cariaco, Venezuela. Aquaculture, 182: 91-114.

Lodeiros, C., D. Pico, A. Prieto, N. Narváez and A. Guerra. 2002. Growth and survival of the pearl oyster Pinctada imbricata (Roding 1758) in suspended and bottom culture in the golfo de Cariaco, Venezuela. Aquacult. Intern., 10: 327-339.

Lodeiros, C., J. Rengel and J.H. Himmelman. 1999b. Growth of Pteria colymbus (Roding, 1798) in the golfo de Cariaco, Venezuela. J. Shellfish Res., 18: $155-158$.

Lodeiros, C., J. Rengel, L. Freites, F. Morales, and J.H. Himmelman. 1998. Growth and survival of the tropical scallop Lyropecten (Nodipecten) nodosus maintained in suspended culture at three depths. Aquaculture, 165: 41-50.

Malavé, C., L. Freites, C. Lodeiros, J. Mendoza, L. Tróccoli and A.W. Dale. 2012. Annual recruitment, predation rates, and biocontrol of Linatella caudata (MOLLUSCA: GASTROPODA) in suspended enclosure culture of the pearl oyster Pinctada imbricata. Aquaculture, 354-355: 75-83.

Márquez, B., C. Lodeiros, M. Jiménez y J.H. Himmelman. 2000. Disponibilidad de juveniles por captación natural de la ostra Pteria colymbus (Bivalvia: Pteriidae) en el golfo de Cariaco, Venezuela. Rev. Biol. Trop., 48(1): 151-158.

Mengual, M., C. Lodeiros y A. Márquez. 2011. Crecimiento y supervivencia de la ostra alada Pteria colymbus (Röding 1798), en estructuras tubulares en la Bahía de Mochima, estado Sucre, Venezuela. Zootec. Trop., 29(2): 219-229.

Müller-Karger, F., G.T. Taylor, Y. Astor, R.C. Thunnell, M.I. Scranton, R. Varela, L. Tróccoli, L. Lorenzoni, E. Montes, K.A. Fanning and C. Benitez-Nelson. 2013. The Cariaco Basin Ocean Time-Series. LOICZ Inprint, 1: 3-17.

Müller-Karger, F., R. Aparicio and R. Castro. 1994. Mesoscale processes affecting phytoplankton abundance in the southern Caribbean Sea. Cont. Shelf Res., 14(2-3): 199-221.

Navarro, J.M. and R.J. Thompson. 1995. Seasonal fluctuations in the size spectra, biochemical composition and nutritive value of the seston available to a suspension-feeding bivalve in a subarctic environment. Mar. Ecol. Prog. Ser., 125: 95-106.

Pilditch, C.A. and J. Grant. 1999. Effect of temperature fluctuations and food supply on the growth and metabolism of juvenile sea scallops (Placopecten magellanicus). Mar. Biol.,134: 235-248.

Prieto, A., O. Ramos, D. Arrieche, J. Villalba y C. Lodeiros. 2001. Producción secundaria e índice de condición en Arca zebra (Molusca: Bivalvia) del golfo de Cariaco, Venezuela. Rev. Biol. Trop., 49: 599-608.

Román, G., M.J. Campos, C.P. Acosta and J. Cano. 1999. Growth of the queen scallop (Aequipecten opercularis) in suspended culture: influence of density and depth. Aquaculture, 178: 43-62.

Saxby, S.A. 2002. A review of food availability, seawater characteristics, and bivalve growth performance at coastal culture sites in temperate and warm temperate regions of the world. Fish. Res. Rep. (W. Australia), 132: 1-42.

Sims, N.A., 1994. Growth of wild and cultured black-lip pearl oysters, Pinctada margaritifera (L.) (Bivalvia, Pteriidae). Aquaculture, 122: 181-191.

Smitasiri, R.R., J. Kajitwimat and P. Tantichodok. 1994. Growth of a winged oyster Pteria penguin suspended at different depths. Phuket Mar. Biol. Cent. Spec. Publ., 13: 213-216.

Sokal, R.R. and F.J. Rohlf. 1979. Biometría. Principios y métodos estadísticos en la investigación biológica. Blume, Madrid. 832 p.

Strickland, J. and T. Parsons. 1972. A practical handbook of seawater analysis. Bull. Fish. Res. Board Canada, 167, 310 p.

Thompson, R. and B. MacDonald. 1991. Physiological integrations and energy partitioning. In: An international compendium of scallops' biology and culture. Shumway, S. and P. Sandifer (Eds.). Workshops World Aquac. Soc., Baton Rouge, 14(1): 28-35.

Tomaru, Y., Y. Kumatabara, Z. Kawabata and S. Nakona. 2002. Effect of water temperature and chlorophyll abundance on the shell growth of Japanese pearl oyster, Pinctada fucata martensii, in suspended culture at different depths and sites. Aquaculture Res., 33: 109-116.

Urban, H.J. 2001. Reproductive strategies in tropical bivalves (Pteria colymbus, Pinctada imbricata and Pinna carnea): Temporal coupling of gonad production and spat abundance related to environmental variability. J. Shellfish Res., 20: 1127-1134.

Urban, H.J. and J.M. Riascos. 2001. Estimating gonado-somatic indices in bivalves with fused gonads. J Shellfish Res., 21(1): 249-253.

Velasco, L.A. and J. Barros. 2010. Spat collection and experimental culture of the Atlantic pearl oyster, Pinctada imbricata (Bivalvia: Pteriidae), under suspended conditions in the Caribbean. J. World Aquacult. Soc., 41: 281-297.

Villarroel, E., E. Buitrago and C. Lodeiros. 2004. Identification of environmental factors affecting growth and survival of the tropical oyster Crassostrea rhizophorae in suspended culture in the golfo de Cariaco, Venezuela. Rev. Cient. Facult. Cienc. Veterin., Univ. Zulia, 14: 28-35. 
Yukihira, H., J.S. Lucas and D.W. Klumpp, 2006. The pearl oysters, Pinctada maxima and P. margaritifera, respond in different ways to culture in dissimilar environments. Aquaculture. 252: 208-224.

Yukihira, H., J.S. Lucas and D.W. Klumpp. 2000. Comparative effects of temperature on suspension-feeding and energy budgets of the pearl oysters Pinctada margaritifera and P. maxima. Mar. Ecol. Prog. Ser., 195: 79-188.

Zhang, J.H., J.G. Fang and X.M. Liang. 2010. Variations in retention efficiency of bivalves to different concentrations and organic content of suspended particles. Chin. J. Oceanol. Limn., 28: 10-17.

Zhou Y. and J. Pan. 1999. Species, distribution, and damage of Cymatium in seawater pearl oyster culture zones of Hainan Island. Trop. Oceanog., 18(1): 83-89.

RECIBIDO/RECEIVED: 20/11/2018

ACEPTADO/ACCEPTED: 05/09/2019 